\title{
The relationship between ownership and possession: observations from the context of digital virtual goods
}

Article

Accepted Version

Watkins, R. D., Denegri-Knott, J. and Molesworth, M. (2016) The relationship between ownership and possession: observations from the context of digital virtual goods. Journal of Marketing Management, 32 (1-2). pp. 44-70. ISSN 14721376 doi: https://doi.org/10.1080/0267257X.2015.1089308 Available at https://centaur.reading.ac.uk/79213/

It is advisable to refer to the publisher's version if you intend to cite from the work. See Guidance on citing.

To link to this article DOI: http://dx.doi.org/10.1080/0267257X.2015.1089308

Publisher: Taylor \& Francis

All outputs in CentAUR are protected by Intellectual Property Rights law, including copyright law. Copyright and IPR is retained by the creators or other copyright holders. Terms and conditions for use of this material are defined in the End User Agreement.

www.reading.ac.uk/centaur 
Central Archive at the University of Reading

Reading's research outputs online 


\title{
The Relationship between Ownership and Possession: Observations from the Context of Digital Virtual Goods
}

Rebecca D. Watkins, Janice Denegri-Knott and Mike Molesworth

This is a post-print copy. The final, published version of the paper can be accessed here:

http://dx.doi.org/10.1080/0267257X.2015.1089308

Cite as: Watkins, Rebecca D., Janice Denegri-Knott and Mike Molesworth (2016), "The Relationship between Ownership and Possession: Observations from the Context of Digital Virtual Goods, "Journal of Marketing Management, 32(1-2), 44-70.

\begin{abstract}
This theoretical paper highlights limitations in the current trend towards dichotomizing full ownership and access-based consumption by recognizing a broader, more complex array of 'fragmented' ownership configurations in the context of digital virtual goods (DVGs). In challenging this dichotomy we recognise that the relation between ownership and possession becomes particularly significant. We therefore consider how prominent DVG ownership configurations may shape the way in which possession is assembled, potentially reducing consumers' scope of action relative to DVGs and leaving possession susceptible to disruption. Conversely, we acknowledge ways in which consumers' continued attempts at possession may impinge upon the agency of ownership mechanisms within the market. Our analysis ultimately builds upon existing understandings of both ownership and possession, theorizing their often overlooked relation in consumption.
\end{abstract}

Keywords: ownership, possession, property rights, digital virtual consumption, digital virtual goods, 


\section{INTRODUCTION}

Recent years have seen suggestions of consumers moving away from ownership towards access-based consumption. However claims of a 'post-ownership economy' (Belk 2013b) or 'age of access' (Rifkin 2000) assume a position that dichotomizes full ownership (total, exclusive rights to goods) and access-based (temporary, limited use of goods) modes of consumption that may obscure significant fragmented or partial ownership configurations and the enduring significance of possession.

The limitations of this dichotomy become particularly apparent in the context of a range of digital goods and services. Our 'possessions', the things we call our own, increasingly extend beyond the tangible. We may use the term 'digital virtual goods' (DVGs) to describe objects which cannot be used in material reality but exist within digital virtual spaces (see Denegri-Knott \& Molesworth, 2010), accessed via devices such as laptop computers, mobile phones and videogame consoles. This trend has been well documented (see Belk, 2013a; Denegri-Knott and Molesworth, 2010; KoisoKanttila, 2004; Lehdonvirta, 2012; Molesworth \& Denegri-Knott, 2012; Rowley, 2008) and we can observe a broadening array of DVGs; alongside locally stored digital photographs, eBooks and digital music we have witnessed the emergence of digital content hosted online by social media platforms, email providers and online games.

DVGs have been implicated in the move to assess-based consumption, credited with potential to liberate consumers from the burdens of ownership (Belk, 2013a, 2013b; Bardhi, Eckhardt \& Arnould, 2012; Rifkin, 2000; 2014; Shaefers et al. forthcoming) and championed as candidates for communal sharing (Belk 2010, 2013a, 2013b; Giesler, 2006) and short-term access (Bardhi \& Eckhardt, 2012). They are seen to be malleable and vaporous enough to fulfil consumers' functional, situational, and identity needs without the responsibilities associated with ownership (Bardhi et al, 2012). Such 'access-based' (Bardhi and Eckhardt, 2012) or 'non-ownership' (Moeller and Wittkowski, 2010) consumption apparently positions ownership as too cumbersome to keep up with the speed of delivery offered by Internet enabled platforms (Rifkin, 2002). Indeed, recent years have seen the emergence of an array of digital access-based business models. Netflix, for instance, reached 
44 million subscribers in January 2014 (Garrahan, 2014), whilst the number of paying Spotify subscribers doubled to 10 million in the 18 months prior to May 2014 (Cooks, 2014).

However, we propose that many DVGs cannot be classified as either fully owned or merely accessed, and that a recognition of an array of 'fragmented' ownership configurations is required in order to understand new models and market systems.

In breaking down the ownership-access dichotomy we recognise that the relation between ownership and possession becomes particularly significant. In prior studies of material possession objects were assumed to be owned 'in full' and consequently ownership and possession are conflated with any relationship between them unproblematic and therefore made absent. Conversely, consumers apparently rarely desire to possess goods that are merely accessed temporarily (Bardhi \& Eckhardt, 2012). Despite the rhetoric of access, consumers may still desire to possess and form meaningful bonds with DVGs (see Denegri-Knott, Watkins \& Wood, 2012; Odom, Zimmerman \& Forlizzi, 2011; Watkins \& Molesworth, 2012; Wang, Zhao and Bamossy 2009) and where fragmented, partial ownership configurations emerge in this context it begs the question of how consumers' limited ownership may shape such possession. The risk of maintaining an ownership/access dichotomy is to obscure not only fragmented ownership configurations, but also the implications of these configurations for how people, things, other people and devices relate in 'possession'.

We draw from ideas in the actor-network theory tradition (see Latour, 2005; Law, 2004, 2008) to propose that ownership configurations may shape the way in which possession is assembled, and vice versa. We consider both how fragmented ownership may reduce consumers' scope of action relative to how DVGs are possessed and leave possession susceptible to disruption, and conversely, how consumers' continued possession attempts may impinge upon the agency of ownership mechanisms within the market. In doing so we build upon existing understandings of both ownership and possession and, more significantly, their relation, uniting the disparate bodies of work that have defined ownership as legal or socially recognised rights to an object and have conceptualised possession as a relationship to an object characterised by proprietary feelings and self-identification. 
We begin by considering the separation of ownership and possession within marketing and consumer research, and proceed to discuss how actor-network theoretical principles may reveal their connection in new ways. In moving beyond the access-ownership dichotomy we then map out a range of prominent ownership configurations in the DVG market, before exploring their potential impact upon consumer possession practices and noting related market implications. We conclude with a summary of our contribution and a discussion of implications for further research.

\section{THE SEPARATION OF OWNERSHIP AND POSSESSION}

In both marketing practice and the day-to-day lives of consumers the roles of both ownership and possession are significant. Intellectual property (IP) represents a large proportion of the value of businesses (Ryder \& Madhavan, 2014), whilst almost everything consumers do involves possessory relationships and property rights (Rudmin, 1988). Consequently these concepts have been the subject of significant study in law, economics, philosophy, psychology and anthropology (see for example Beaglehole, 1932; Locke 1690 [1967]; Macpherson, 1978; Munzer, 1990; Rudmin, 1988, 1991; Schlatter, 1951), alongside marketing and consumer research (for example Ahuvia 2005; Bardhi Eckhardt and Arnould 2012; Belk 1988; Epp and Price 2010; Price Arnould and Curasi 2000). The connection between ownership and possession, however, remains vague.

Inattention to this relationship may be rooted in two key tendencies: (1) the consideration of possession at the micro level of the agentic consumer subject, separate from studies of ownership that are more often located at a meso, or macro level, and (2) a presentation of ownership in the marketing and consumer research literature as a total, coherent concept that renders its relationship to possession as apparently unproblematic. In this section we consider the emergence of these tendencies, and the ways in which challenging them may enrich our understanding of contemporary ownership and possession.

\section{Defining ownership and possession}

Ownership is generally defined as a legally and/or socially sanctioned arrangement between people with respect to a thing and other people, where the 'thing' in question may include land, 
material objects, or even ideas (Gaus, 2012; Munzer, 1990). Three major approaches to ownership have been dominant in the last century of political and legal thought: Full Liberal Ownership, Bundle and Integrated theories.

Full Liberal Ownership approaches assume ownership in toto, including a) unlimited use of a resource b) ability to exclude others and c) rights of transfer (sell, gift, destroy) (Honoré, 1961). From this perspective ownership is 'that sole and despotic dominion which one man claims and exercises over the external things of the world, in total exclusion of the right of any other individual in the universe' (Blackstone cited Grey, 1980, p.75). In discussions of access-based consumption and a 'post-ownership economy' (Bardhi \& Eckhardt 2012; Belk 2010, 2013b; Chen, 2009; Moeller and Wittkowski 2010; Rifkin, 2000) ownership is presented in line with such Full Liberal Ownership approaches, existing in full or not at all. However legal scholars have long argued that this approach has lost its relevance due to a 'fragmentation' of ownership that became apparent in the $20^{\text {th }}$ century. A key proponent of Bundle Theory, Grey (1980) has pointed out that in the late $20^{\text {th }}$ century the law was no longer dealing with ownership as a cohesive authority over things. Instead, ownership should be conceptualized as a 'bundle of sticks', each representing a right regarding the object of ownership (for instance, the right of control, of exclusion, or of disposition), and where 'sticks' or rights can be distributed in varying ways amongst a range of 'owners' (Hofhed, 1901 cited in Munzer, 1990).

Integrated approaches accept that whilst ownership may be fragmented amongst different owners, specific rights over a resource remain organised in some coherent fashion (Attas 2006, Gaus 2012). For example, Attas $(2005,2006)$ sees ownership as having both content (specific rights with respect to the 'thing' in question) and form (the characteristics of the rights themselves). Here the content of ownership consists of control rights (the right to access an object, use it as one wishes, and manage who uses it and how) and income rights (entitlement to advantages that emerge from direct action upon the object). These rights themselves vary in form, which Attas considers in terms of continuity (the right's duration and whether it can be lawfully be taken from the consumer) and transferability (the extent to which rights can be transferred to another party). 
From this perspective goods are neither fully owned nor not owned; variations in content and form instead produce a diverse spectrum of ownership configurations. A range of common configurations are frequently discussed in law, such as usus (right to use or enjoy an object of ownership without altering it), fructus (right to derive profit from this object) and usufruct (unites rights of usus and fructus), however Attas' work calls for a recognition of a much broader array of ownership configurations. In drawing particularly from the work of Attas $(2005,2006)$, we propose that the apparent reduction in the importance of ownership noted in previous work (Bardhi \& Eckhardt, 2012; Belk, 2013a; Chen, 2009) might alternatively be interpreted as evidence of an ongoing reconfiguration of rights.

Within the macromarketing literature there is already recognition of fragmented ownership forms. For instance the Bundle Theory approach has been used by Haase and Kleinaltenkamp (2011) in their study of property rights theory and co-creation where they define ownership as a contractual mediator between market actors operating on a dual plane; one in relation to owning resources outright (typical of most commodity exchange) and the other to the right to use that resource in a particular way (as in the case of services businesses). However such meso or macro level analysis offers little insight into how ownership may relate to possession in these contexts. Elsewhere the marketing literature considers ownership in the context of DVGs, typically steered by either an ethical mandate to account for the discourses that justify ownership arrangements of digital content (DenegriKnott, 2004; Nill and Geipel, 2010; Giesler, 2008), accusations of exploited consumer labour (Bonsu \& Darmody, 2008; Ritzer \& Jurgenson, 2010; Scholz, 2012), concerns surrounding copyright infringement (Peitz \& Waelbroeck, 2006; Phau, Tea \& Lwin 2014; Sundararajan, 2004), or interest in the tensions and conflicts between co-producing parties (Harwood and Garry, 2010, 2014). However despite this work on ownership in digital contexts we still lack an understanding that relates DVG ownership configurations to possession.

In contrast to ownership as socially or legally recognised rights to an object, the term 'possession' usually implies personal identification with the item as an extension of the self (Belk, $1982,1983,1988)$ and refers to "things we call ours" (Belk 1988, p.139) regardless of whether we 
legally own them. This use of the term is akin to discussions of 'psychological ownership' in psychology, distinct from legal ownership and defined as 'the state in which individuals feel as though the target of ownership, or a piece of that target is "theirs" (Pierce, Kostova \& Dirks, 2003, p.85). Thus possession is distinct from the rights to interact with objects in certain ways (ownership), but refers to a conviction that something is ours and is part of who we are. As Belk notes, "to possess something, whether legally or not, involves proprietary feelings" and to acquire these feelings it "may be necessary to perform certain possession rituals" (Belk 2014, p.33-34). Possessions become distinct from commodities (defined by their exchange value), since they have become subjectified (Miller, 1987) or singularized (Kopytoff, 1986), and thus separated (at least temporarily) from the commodity sphere. Merely touching an object may lead to a sense of perceived ownership or possession (Peck and Shu 2009), but usually coming to possess objects involves practices such as cleaning (McCracken 1986, Gregson and Crewe 2003) and personalizing items (Belk et al 1989), and singularisation over time as objects' histories become interwoven with our own (Belk 1990; 1991; Grayson and Schulman 1990), whilst appropriation may also result from habituation through use (e.g. the chair in the coffee shop or classroom that is 'my' chair). Through such processes possessions can become receptacles of public and personal meanings (Richins, 1994a; Richins, 1994b; Wallendorf and Arnould, 1988), and utilised as resources for identity projects (Ahuvia, 2005; Belk 1988; Kleine, Kleine and Allen, 1995). Thus possession becomes more than just a psychological phenomenon as it involves practices of using, controlling, caring for and managing objects of possession.

Such acts assume a level of control that may be enabled or restricted by ownership. We might assume that it is only under conditions of full ownership that consumers can engage in the curatorial, ritualistic or habitual practices needed to transition commodities into personal possessions, for example. Yet we hold a limited understanding of this relationship as much of what consumers have previously possessed has also been owned 'in full'. Despite acknowledgement that consumers may legally own a good but never view it as truly belonging to them (McCracken, 1986), or may view goods as possessions despite a lack of legal ownership (Belk, 1988; Etzioni, 1991; Pierce et al, 2003), 
within marketing literature our understanding of the inter-relation of ownership and possession remains limited.

\section{Relationships between ownership and possession}

A relationship between ownership and possession has already been suggested by Rudmin's $(1988,1990)$ intellectual history of the psychology of property that brings together cognitive and utilitarian philosophies to explain that the only way in which objects can provide the security necessary to guarantee expectation of future use and enjoyment is total ownership. Once an object of consumption is owned in full one can imagine future uses and enjoyments, and these guarantees are provided through societal approbation and by the sanction of the law. Further afield, the ownershippossession couplet has also been supported on moral grounds. Ownership is needed because it provides the space and privacy required for the cultivation of goods as expressions of one's identity and personality as acts of will (Demsetz, 1967; Munzer, 1990; Hegel, 1967 [1821]; Snare, 1972). Thus when these guarantees are missing, for instance when a good is rented, borrowed or stolen, consumers' identity work and singularising attempts, and thus possession, may be compromised. Legal analysts have noted that if full ownership is missing, possession can be 'bizarre and unstable' (Munzer 1990). Possession of objects that may be acquired illicitly are, according to Litwinski (cited in Rudmin, 1990), not properly possessed because they fail on the requirement that future use is guaranteed. The illegal MP3 therefore, following Litwinski's line of argument, may be akin to a stolen apple in its 'tense and tenuous possession' (Rudmin, 1990, p. 317) because it lacks the social approval needed to enjoy listening openly and guilt free.

More recently, linkages between possession and ownership have been implied in research into new modes of consumption in situations of non-ownership. This is seen in the shift from (full) ownership to access (e.g. Bardhi \& Eckhardt 2012; Belk 2013b; Durgee and O'Connor 1995; Chen, 2009; Moeller and Wittkowski 2010; Rifkin, 2000), whereby access-based consumption represents 'transactions that may be market mediated in which no transfer of ownership takes place' (Bardhi \& 
Eckhardt 2012, p.1). Instead the individual merely acquires 'consumption time' with the object, through either market-mediated models such as renting (Bardhi \& Eckhardt, 2012) or non-market mediated access models such as sharing (Belk, 2010; Ozanne \& Balletyne, 2010) and borrowing (Jenkins, Molesworth \& Scullion, 2014). For Bardhi and Eckhardt (2012) the major differences between ownership and access reside in the nature of the rules governing the object-self relationship. For example, in their Zipcar study the limits to possession adopt the form of a Big Brother governance model where use is monitored in order to prevent damage to the cars. When renting cars there is an emphasis on short term use value and acts that might facilitate appropriation such as caring for, cleaning and personalising cars are not performed (Bardhi and Eckhardt, 2012).

Regardless of suggestions in the literature that ownership and possession may be linked there is little elaboration of this relationship. This may be due to the tendency to separate ownership and possession as discrete areas of study with macro-level marketing research dealing with ownership taking place separately from micro-level studies of consumer experiences of possession to the extent that separate journals and conferences have been established for their study. Indeed Slater (2011) proposes that marketing has been rendered impossible by a process of 'purification' which has led to divisions between economics and the cultural disciplines, with economics largely ignoring cultural factors in its analysis of formal rationality, whilst cultural disciplines focus on meaning-making, often disregarding commercial aspects of consumption practices. Consequently we lack an understanding of the ways in which ownership may shape the possession of goods and, vice versa, how a desire to possess may shape both legal and technical systems of governance and the creation of new market offerings.

Again, this may have been relatively unproblematic when those material goods consumers possessed tended to be fully owned, for instance a beloved family table (see Epp and Price 2010) or vintage purse (see Ahuvia 2005). In contrast, consumers appear to have little desire to possess objects that are merely accessed temporarily such as rented cars (Bardhi and Eckhardt 2012), once again rendering the relation between ownership and possession apparently of little importance. However, the apparent reduction in importance of ownership noted in assess-based consumption research (Bardhi 
and Eckhardt 2012, Belk 2013b, Chen, 2009) might be seen as a manifestation of the fragmentation of ownership rights. That is, in many cases ownership is not absent but rather is present in fragmented forms that distribute rights to use objects in specific ways. This does not necessarily mean that the importance of ownership recedes as has been claimed, but rather that ownership continues to moderate consumers' objectual relationships, but in new and possibly restrictive ways that require a better understanding of how ownership and possession act upon each other.

\section{REALITIES OF OWNERSHIP AND POSSESSION}

In order to overcome problems arising from this 'purification' of ownership and possession in marketing and consumer research we might: (1) recognise them as distinct, but always linked entities, and; (2) discard attempts to understand them as essentialist, finite concepts and instead approach them as concurrently produced, stabilised, and de-stabilised entities.

Such intervention is possible by adopting principles from actor-network theory (ANT) (see Latour, 2005; Law, 2004, 2008). ANT treats "everything in the social and natural worlds as a continuously generated effect of the webs of relations within which they are located", arguing that no entity exists outside of such webs (Law, 2008, p. 141). Work within the ANT tradition typically adopts a distinct set of principles, including most prominently the notions of relational materiality (reality is enacted or performed by networks of heterogeneous actants and it is in these relations that agency is located), and ontological symmetry (divisions such as subject/object or nature/culture exist only as enacted rather than a priori) (Latour, 2005; Law 2004). How then does such a perspective shift the way in which we view ownership and possession?

ANT necessarily rejects claims that there could be an ex ante notion of either 'possession' or 'ownership'. Possession, for instance, must rather be approached as a patterned relation between things, people, devices, and knowledge that become aligned in a particular way when possessing takes place. This means that in making sense of ownership and possession we might trace movement, or translations in their networks, understanding them as relational matter. In particular ontological symmetry calls for a flat ontology that avoids a priori privileging of actants. Often in the literature we 
find that material possessions are presented as ontologically inferior, passive targets of human action (consumers, marketers or lawyers, for example). Within consumer research, for example, agentic consumer subjects are privileged as they cultivate their possessions' meanings, move them through various stages in their biographies, and employ them in identity projects. Other necessary elements in possession, for instance the objects themselves, storage space, locks and keys, digital devices and people needed in performing possession are made manifest absent (Law, 2004), with limited exceptions (see Epp and Price, 2010); from an ANT perspective we might observe that complex assemblages are 'black boxed', hiding actants and their agency (Latour, 2005). This is in keeping with a broader tendency within interpretivist consumer research to take the consumer as the primary unit of analysis, disregarding aspects of consumer culture which do not present themselves in consumers' lived experiences (Askegaard \& Linnet, 2011; Moisander, Peñaloza \& Valtonen, 2009; Moisander, Valtonen \& Hirsto, 2009) and overlooking non-human sources of agency (Badje, 2013). Increasingly, however, consumer research has moved beyond such micro level analyses (e.g. Arsel \& Thompson, 2011; Giesler, 2012; Bettany and Kerrane 2011; Scarabato \& Fischer 2013), and studies of possession have already begun to consider non-human agencies. For instance, Bardhi et al (2012) consider how global nomadism produces liquid relationships with possessions, whilst Epp and Price (2010) explore the influence of a range of actors from identity practices to competing consumption objects. Ownership, however, remains largely overlooked within these analyses despite its significant role in enacting or assembling possession.

We might acknowledge that possession in a market society has historically attained stability via 'ownership' acting to set preferential ways in which different elements (objects, devices, ways of doing) come together in 'possessing'. From an ANT perspective this may also be understood as ontological politics (Mol, 1999; Law 2004). Realities are assembled, but in any one case we might ask which actants' purposes are best served in that reality and in ensuring that alternatives are not enacted. 'Ownership' makes certain configurations of possession possible while denying others, making it more likely that certain arrangements can be enacted and stabilised. 
Let us illustrate this. In the case of a rented house, ownership links people to the property and to each other in ways that may vary greatly; some will only be able to reside in the property but not modify it, whereas others will be able to profit from the property through rental or sale under certain conditions, and at certain times modify it (Attas, 2006; Gaus, 2012). All, however, may call the house 'theirs', even as they hold different objectual relations with the house (and to each other) and hence different means of enacting possession. In this sense, we can see how ownership acts to define how different actants (things and people) should relate in possessing and so shapes the realities of how possession is enacted. This is equivalent to the role that has been attributed to economic and business theories in the making of market performances, spaces, subjects and actors (Araujo, 2006; Callon, 1997; Cochoy, 1998; MacKenzie Muniesa and Siu and 2007; Slater 2002) and indeed such theories also remain active in how ownership and possession are shaped and re-shaped.

While there are many possible permutations, some ownership configurations are already captured by Attas' (2006) work and we now repurpose this as scaffolding. Specifically, possible combinations of content and form in ownership rights specify how, by whom and for how long an object can be used, modified and moved along or transferred (Attas, 2006). Returning to our example of a house, we see that for a tenant the house can be accessed and used for the period of the lease, but he has a restricted ability to modify or profit from it. For the landlord, on the other hand, typically the home cannot be accessed or used during the tenancy, however she may hold enduring rights to manage use of the home (to evict and select tenants, and to restrict their use of the property), to modify the house (to re-decorate and build extensions) and to profit from it (via selling or leasing). In this example we see ownership shaping possession upon three general dimensions: control-the degree of agency a consumer has over an object in its use; continuity - the duration for which a consumer is awarded access to and agency over an object, and finally; transferability - the ability to move an object through its cycle of biography, either through divestment, gifting, exchange or destruction.

Ownership is not simply abstract however, but also involves: a legal system which details how property rights can/should be distributed; legal and law enforcement professionals (lawyers, judges, police, prison guards) who understand and enforce this legal system; related materials (including 
courts, prisons, locks, home security systems; property law documents, contractual agreements and purchase receipts), and; law-abiding consumers who are aware of, and motivated to abide by property rights legislation. Thus ownership configurations are enacted by complex heterogeneous networks of actants that for much of the time remain manifest absent (see Law 2004). We don't notice them despite their necessity. Indeed their role only becomes apparent when something 'breaks', for example when a contract is breached or something is stolen. However, the apparent stability of ownership masks the considerable actor-network required to maintain assemblages in this way.

This is significant when we consider DVGs. Digital technologies reveal new actors and relations and therefore new realities of ownership and possession, and opportunities for changes in ontological politics. For example, this is captured by Lessig's (1999) observations about the role of code in regulating behaviour:

"In real space, we recognize how laws regulate- through constitutions, statutes, and other legal codes. In cyberspace we must understand how different "code" regulates- how the software and hardware (i.e. the "code" of cyberspace) that makes cyberspace what it is also regulate cyberspace as it is" (p.5)

Seen from an ANT perspective, Lessig's concern is the power of code as an actant that renders other agencies impotent, in particular those relating to legislation and social norms. Code does away with human and material aspects of ownership and possession networks such that only certain realities can be assembled. Code is ontological politics in action. Although we might see code as only enforcing the will of the lawyers and managers, this would be to assume that software is merely an intermediary (doing no more than transporting existing agencies) and to make manifest absent the agency of the code itself which continues to restrict behaviour, just as locks and alarm systems continue to act to deny unauthorised access to our homes long after they have been manufactured and installed In an ANT sense then, software might be understood as a mediator, significant and able to change the network, and with the agency distributed amongst this network there is the possibility of interference by other actants at any point. 
We now see this proposed analytic in action by describing prominent DVG ownership configurations and their relation to how DVGs may be possessed, according to core themes emerging from the available literature on possession.

\section{PROMINENT DVG OWNERSHIP CONFIGURATIONS}

In acquiring, using and accessing DVGs consumers must agree to End-User License Agreements (EULAs) and/or Terms of Use/Service contracts that typically include restrictions on their use. Such agreements set out specific ways to enact possession by distributing bundles of rights that vary in content, (dictating how DVGs are to be used, modified, or profited from), and form, (restricting for how long they may be possessed and whether they may be gifted, bequeathed or sold). We capture dominant configurations in Figure 1, the grey areas representing a 'distance' from full ownership, with the darker areas indicating the greatest divergence. We include examples of 'full ownership' (a purchased table as in Epp and Price's (2010) study) and of 'access' (a hire car as studied by Bardhi and Eckhardt (2012)) as well as examples of DVGs to illustrate the way digital technologies allow for positions in between these two configurations.

Figure 1- Prominent ownership configurations in DVG markets

\begin{tabular}{|c|c|c|c|c|c|c|}
\hline & \multirow[t]{2}{*}{ Full Ownership } & \multicolumn{4}{|c|}{ DVG Ownership Configurations } & \multirow{2}{*}{$\begin{array}{c}\text { Market- } \\
\text { Mediated } \\
\text { Access }\end{array}$} \\
\hline & & $\begin{array}{c}\text { Created, Local } \\
\text { content }\end{array}$ & Hosted Content & $\begin{array}{c}\text { Non- } \\
\text { Transferable } \\
\text { Licence }\end{array}$ & $\begin{array}{c}\text { Subscription } \\
\text { Based Services }\end{array}$ & \\
\hline Examples & Kitchen Table & $\begin{array}{l}\text { Locally stored } \\
\text { photographs \& } \\
\text { documents }\end{array}$ & $\begin{array}{l}\text { Facebook profile, } \\
\text { Flickr album, } \\
\text { content within } \\
\text { online games }\end{array}$ & $\begin{array}{l}\text { iTunes album, } \\
\text { Amazon eBook }\end{array}$ & Spotify, Netflix & Hire Car \\
\hline Right to Use & Unrestricted & Unrestricted & Restricted & Restricted & Restricted & Restricted \\
\hline
\end{tabular}




\begin{tabular}{|c|c|c|c|c|c|c|}
\hline $\begin{array}{c}\text { Right to } \\
\text { Transform }\end{array}$ & Unrestricted & Unrestricted & Restricted & Denied & Denied & Denied \\
\hline $\begin{array}{l}\text { Right to } \\
\text { Income }\end{array}$ & Unrestricted & Unrestricted & Restricted & Denied & Denied & Denied \\
\hline Transferability & Unrestricted & Unrestricted & Restricted & Denied & Denied & Denied \\
\hline Continuity & $\begin{array}{l}\text { Permanent, } \\
\text { subject to } \\
\text { material space } \\
\text { and security } \\
\text { (locks). }\end{array}$ & $\begin{array}{l}\text { Permanent - } \\
\text { with licenced } \\
\text { software and } \\
\text { hardware }\end{array}$ & $\begin{array}{c}\text { Indefinite- } \\
\text { Requires active } \\
\text { account, } \\
\text { platform, and } \\
\text { local hardware }\end{array}$ & $\begin{array}{c}\text { Indefinite- with } \\
\text { licenced software, } \\
\text { hardware \& active } \\
\text { account }\end{array}$ & $\begin{array}{c}\text { Temporary- } \\
\text { Requires active } \\
\text { account, platform, } \\
\text { and local hardware }\end{array}$ & $\begin{array}{c}\text { Temporary, } \\
\text { subject to locks } \\
\text { and security } \\
\text { devices. }\end{array}$ \\
\hline $\begin{array}{c}\text { Typically } \\
\text { enforced by: }\end{array}$ & $\begin{array}{c}\text { Local legal } \\
\text { systems }\end{array}$ & Coding & $\begin{array}{c}\text { Contractual } \\
\text { agreement, } \\
\text { surveillance \& } \\
\text { coding }\end{array}$ & $\begin{array}{l}\text { Contractual } \\
\text { agreement, } \\
\text { surveillance \& } \\
\text { coding }\end{array}$ & $\begin{array}{l}\text { Contractual } \\
\text { agreement, } \\
\text { surveillance \& } \\
\text { coding }\end{array}$ & \begin{tabular}{|c|} 
Contractual \\
agreement. \\
Legal systems
\end{tabular} \\
\hline
\end{tabular}

Ownership rights are more easily enforced in the DVG market where surveillance and monitoring are possible through digital technologies and access can be withdrawn or modified without a reliance on legal systems and professionals (e.g. a World of Warcraft account may be closed and ingame content 'reclaimed' by Blizzard Entertainment without any call to law enforcement agencies or bailiffs, or the presentation of evidence). Lessig (1999) has already proposed that 'code is law' and companies now encode restrictions into digital content themselves as automated forms of enforcement that replace the agency of material and human actors. Just as Watson and Shove (2008) describe the re-distribution of competence as skill once held by only skilled painters came to be embodied in nondrip paint, here we can observe the displaced agency of social norms and legislative systems as code increasingly supersedes these actants in restricting users' behaviour. Thus we can observe distinct configurations in the context of DVGs, not only in terms of the fragmented bundles of rights consumers hold but also in the re-distribution of agency. We now explore four prominent ownership configurations: created, local content; non-transferrable licences; hosted content, and; subscription based services.

\section{Created, Local content}


Some DVGs align closely with the established full ownership configurations, as in the case of locally stored DVGs created by and stored on consumer's own devices outside of contractual agreements, for instance in the case of a photograph we have taken on our camera and stored locally on our laptop. The preferential way of practicing possession is defined by a set of relationships between consumers, hardware (computers, cameras and various disc drives), software (operating systems and photo-viewing and editing programmes), DVGs, conventional practices of storing photographs and computer use, personal projects and goals and levels of commitment to photography and memory keeping. The experience of possession, however, is relatively stable, secure and continuous. Such photographs can be viewed as many times as desired, transferred to other devices, transformed with (licenced) photo-editing software, printed, sent to whom we like, and even sold for profit (a licence or a printed copy). However, the enactment of such DVGs as possessions, unlike material goods still remains reliant on other devices doing their bit. Access, alongside the ability to modify, copy, and store, requires hardware and software with related licences. Thus even here we observe new actants embroiled in possession and the possibility that the actions of one such actant may destabilise what is experienced as permanent ownership; a hard drive might fail or the software used for viewing photographs may require an update, temporarily or permanently denying use.

\section{Subscription Based Services}

A different, but now prominent ownership configuration operates for subscription-based services such as Spotify and Netflix that enables users to stream media so long as they continue to pay a monthly subscription fee, and here it is clear to users that they do not own the content stored on the companies' servers. These configurations draw parallels with discussions of access-based consumption, liquid and temporary access to large archives of digital media reliant on subscription to a service alongside a computing device and internet access, and with the complex data storage, server systems, and licensing agreements often made absent. In subscription-based services, software takes responsibility for maintaining, or denying access controlled by accounts and passwords.

An access-ownership dichotomy might lead us to compare and contrast these extremes created, local content and subscription based services draw parallels with prior comparisons of full 
ownership and access. However Figure 1 also acknowledges fragmented ownership configurations hosted content and non-transferable licences - that present new configurations of ownership.

\section{Non-transferable licences}

In downloading digital music, films and eBooks from platforms such as Apple's iTunes store, Amazon's Kindle Store, or Google's Play Store the consumer purchases a non-transferable licence to consume these DVGs in restricted ways. For instance, a consumer may be granted the right to access an eBook only so long as they hold an active account, have access to compatible hardware and software, and abide by the agreed Terms of Service. They may not be permitted to read the eBook on a competing device, and are likely denied the right to transfer (they may be unable to pass on the eBook to a friend) or to appropriate returns (they will be unable to re-sell). Companies will also typically reserve the right to terminate accounts where consumers are deemed to have breached the contractual agreement, whilst digital rights management (DRM) technologies may be used to limit use, rather than legal and law enforcement actants.

\section{Hosted content}

Finally, hosted content - DVGs which are created in part by the consumer but that exist online (e.g. a Facebook account and uploaded and posted content, avatars and content within online games). - also presents new configurations of ownership. Such user generated content contributes significant value to many online platforms (Bonsu and Darmody 2008; Ritzer and Jurgenson 2010) and whilst arguments justifying private property often recognise the link between one's effort and ownership (Locke, 1690 [1967]), in reality, ownership here is limited. For instance whilst Facebook's terms of service declare that 'You own all of the content and information you post on Facebook' the consumer simultaneously grants Facebook a 'non-exclusive, transferable, sub-licensable, royalty-free, worldwide license to use any IP content that you post on or in connection with Facebook' (Facebook, 2014). Consumers' rights to use and transform such hosted content (within the limits of available code, and abiding by contractual agreements) are often non-transferable and bound to a single individual. 
In some cases hosted content may be transferred and even re-commodified, however such instances are rare and restrictions may still be in place. For instance content within virtual world Second Life can be sold for Linden dollars (in-world currency) that can be converted to traditional offline currency, however the transfer of accounts themselves is forbidden without prior written consent from Linden Lab (Linden Research, 2014). In the case of the massive multiplayer online game World of Warcraft consumers may exchange items within the game itself but 'may not sell ingame items or currency for "real" money, or exchange those items or currency for value outside of the Game' (Blizzard 2014). As with non-transferable licences, where consumers are deemed (by the company) to have breached restrictions, their accounts (and therefore access to their hosted content) may be terminated via code. In such a case our taken-for-granted physical networks of law enforcement and interpretation are again circumvented, and must be re-imposed by consumers with considerable effort if they challenge decisions. Indeed, for hosted content continuity of access is always precarious since access may also be dependent upon continued payment of subscription fees, and on the continuation of platforms themselves.

Thus beyond full ownership and market-mediated access-based consumption we observe fragmented ownership configurations assembled by varying technical and legal boundaries around customer freedoms, which almost always favour the companies' interests. Our proposed taxonomy of DVG ownership configurations in Figure 1 is not intended to be all encompassing, however. Indeed, we recognise that a) other ownership configurations may exist, b) there are variations within each configuration presented, and c) goods may transition between configurations (e.g. a locally stored photograph uploaded to image hosting website Flickr may become hosted content). However this exercise enables us to better consider how these particular permutations enact preferred ways for DVGs to be possessed, as we now proceed to do.

\section{ASSEMBLING DVG POSSESSION}

In this section we consider the implications of the fragmented models of ownership that we have identified for practices of possession that can be contrasted with established possession assemblages 
documented in much extant literature on owned material objects. We organise our analysis around four key themes that emerge as central to past research on possession: cultivation, movement, contamination and stability. In each instance we identify ways in which configurations of ownership may shape this aspect of possession, alongside instances where the agency of ownership configurations may be met with resistance.

\section{Cultivation}

Prior work has examined the ways in which possessions become personally meaningful as consumers invest time, resources, and attention in cultivating their use or maintaining their special stature (Belk et al., 1989; Csikszentmihalyi and Rochberg-Halton 1981; McCracken 1986; Richins, 1994a, 1994b). The work needed to transform personal belongings like a kitchen table (Epp and Price 2010), a car (Lastovicka and Sirianni 2011), a camper van (Belk et al. 1980), or a wedding dress (Lastovicka and Fernández 2005) into precious possessions requires a high level of control. Such objects are generally handled, cared for and modified (Epp and Price 2010, Belk et al. 1989; Lastovicka and Sirianni 2011), and may be gifted (Belk and Coon 1993) or bequeathed (Wallendorf and Arnould, 1988). Such cultivation may be shaped by ownership configurations inasmuch as the ability to access, use and transform goods as described by Attas (2006) is distributed in specified ways. For DVGs consumer agency may be redistributed to software and hardware. For example in the non-transferable licence configuration, consumer control is reduced by restrictions encoded into the DVGs themselves through DRM, data encryption, digital watermarks, and user plug-ins (Manley \& Holley, 2012), now confirmed by legislation. For example the 1998 Digital Millennium Copyright Act (DMCA) in the US prohibits unauthorised access to a work by circumventing such technological protection measures put into place by the copyright owner (Freeman, 2002).

Such measures are seen in the eBook market with both Amazon and Apple applying DRM technologies to the eBooks they sell which, amongst other restrictions, makes them incompatible 
(unusable) with competing devices and applications. We might see this as equivalent to buying a paperback that can only be read with a pair of spectacles purchased from the same bookstore. The implausibility of this analogy reveals the work done by the code in DRM-protected goods. Such restrictions inhibit consumers' control over their eBooks. Imagine, for example, a reader who accumulates a collection of Kindle eBooks but is later gifted a Barnes \& Noble Nook by a loved one. This individual would be unable to legally move their existing content onto their new device since the Kindle Store Terms dictate that Kindle content is used 'solely on the Kindle or a Reading Application' (Amazon, 2014), a restriction enforced by the DRM technology encoded within the eBook itself. Consequently we may come to see eBook collections fragmented across devices and applications and here restrictions not only prevent copyright infringement but may also prevent the cultivation of meaning.

Despite legislation prohibiting such actions however, websites and online forums contain explanations of how to strip DRM from eBooks and so reduce the agency of code in enforcing restrictions on behaviour as consumers seek to share, or simply transfer their content to another device. Thus companies and code may not always successfully assemble ownership in ways that restrict behaviour as intended. This is in line with prior work that documents the ongoing struggle between corporations imposing legal restrictions on digital music consumption and consumers' attempts to resist them (Giesler 2008). Nevertheless, what might seem reasonable use of a purchased eBook may now require actions illegal under ownership legislation. Again an analogy makes the difference clear - if the code acts as law enforcer, the equivalent consumer actions for material goods might be disabling store security and evading police.

Previous research also illustrates that the ability to modify freely facilitates the cultivation of DVGs within videogames (Denegri-Knott et al, 2012; Watkins \& Molesworth, 2012) yet restrictions are commonly placed on the right to transform DVGs. The right to transform is again not only stated in contractual agreements, but also restricted by the customisation options enabled in-game by designers (again, by code and to suit the company). In some videogames extensive customisation options enable the crafting of DVGs that come to feel 'unique'. For example, Watkins and 
Molesworth (2012) describe a process of customisation performed by one video gamer who spends hours redecorating her new house within The Sims to suit her own tastes and desires in order to experience it as her own, noting in contrast that "where "customisation" involved simply choosing from a few pre-determined options attachment was rarely formed' (p. 160). By offering only limited control over objects companies may therefore limit appropriation and meaning making activity, and subsequently DVGs' likely role in consumers identity projects since, as Belk (1988) argues, possessions are often incorporated within our extended self via control and mastery.

Yet consumers' cultivation of DVGs may also be beneficial to corporations seeking online engagement, hence some online business models encourage consumers to craft content, but retain ownership of the outcomes of that labour. For example, the virtual world 'Second Life' is in large part the product of the creative labour of its users (Bonsu \& Darmody, 2008). Similarly, although Facebook is assembled from a coded infrastructure, the servers on which content is hosted, and the website developers who create and maintain the platform, it ultimately relies on the consumer to upload and tag multiple photographs, fill out personal information, and continuously provide the upto-date, socially valuable information that attracts users and therefore advertisers to the platform. Here end-users' crafting of hosted content presents the major contribution to the value of these platforms. A Lockean understanding of property holds that consumers own the products of their labour - that in mixing our labour with an object it becomes ours (Locke, 1690[1967]) - and for Attas $(2005,2006)$ income rights stem logically from control rights, however here consumers are granted the right to create and transform content, but do not benefit from financial advantages arising from this activity. The code allows possession and ownership to be separated such that meaningful possession may be assembled with considerable agency from the user, whilst ownership is retained by the company for the purpose of commercial profit. This system has been subject to critiques based on the exploitation of consumers' labour (Bonsu \& Darmody, 2008; Scholz, 2013) and whilst we cannot fully explore them here we note that some assemblages of ownership in the DVG market raise significant ethical concerns relating to who might benefit from content and in what ways.

\section{Movement}


A second important theme within studies of possession draws on the idea that objects have 'social lives' (Appadurai, 1986) or 'biographies' (Kopytoff, 1986). Research documents second hand markets fuelled by goods repeatedly re-entering the commodity sphere (Belk et al, 1988; Denegri-Knott \& Molesworth, 2009; Gregson \& Crewe, 2003; Lastovicka \& Fernandez, 2005), the passing on of family heirlooms (Price et al, 2000) and practices of sharing and lending (Belk, 2010; Jenkins et al, 2014). Here the consumer moves goods from one stage of their biography to the next (Kopytoff, 1986), however new ownership configurations may limit their ability to do so. Indeed many of the movement practices previously documented may lack a digital virtual equivalent since many DVGs are in effect 'terminal commodities' (Appadurai, 1988) prohibited by code from being re-sold, passed on, or bequeathed. Indeed, as consumers accrue cherished, personally meaningful digital possessions both scholars and consumers are beginning to consider the notions of digital heirlooms and digital legacy (Carroll and Romano 2010; Odom et al 2010, 2012), and yet legal ownership emerges as a key obstacle.

Again commercial motives are implicated in the transformations that may be witnessed. Digital artifacts exhibit pure 'non-rivarly in use' since use of a digital artifact by one person does not affect its simultaneous use by others (Faulkner and Rund 2011). Once a digital artifact exists the cost of providing this non-rival object to an additional user is zero - sending an mp3 file to a friend (or indeed to one million 'friends') does not prevent a consumer from continuing to use it themselves. From a company's perspective however this abundance (Lehdonvirta and Castronova, 2014) has significant consequences. Where DVGs can be duplicated indefinitely exchange value is lost (why would consumers pay for an $\mathrm{mp} 3$ file when another consumer can provide a copy for free?). Consequently companies use code to prevent consumers from engaging in unauthorized sharing (Koiso-Kantilla 2004), but such actions have other consequences for possession.

As an illustration of this, in 2012 actor Bruce Willis was reportedly preparing to sue Apple over the right to bequeath his iTunes music collection to his daughters (Child, 2012). Whilst this claim was later refuted (Arthur, 2012) it raises the question of whether we can indeed pass on our DVGs to others. Legal scholarship highlights this as a grey area due to the existence of much content 
within non-transferable accounts (Wong, 2012). World of Warcraft's Terms of Use, for instance, state that it 'does not recognize the transfer of World of Warcraft Accounts [...] You may not purchase, sell, gift or trade any Account' (Blizzard, 2014). Thus whereas we may have passed down our treasured material possessions to our children, repeating this practice with a World of Warcraft avatar would breach the service's Terms of Use. It appears that (if such restrictions are adhered to) many of our digital virtual possessions will expire with us. Thus the prevalence of family heirlooms, and more broadly the concept of 'second hand goods' with a history of previous ownership, may be eroded as possessions become digital.

Practices of lending are similarly restricted. For example, although Barnes \& Noble enables users to lend certain 'LendMe' compatible eBooks to friends, the length of this arrangement is restricted to 14 days (after which the eBook is automatically returned) rather than socially negotiated between lender and borrower, and unlike material books each eBook may be lent only once (Barnes \& Noble 2014). Here messy and complex social practices of lending through which human bonds are made, reinforced and reflected on (see Jenkins et al 2014) are replaced by straightforward and utilitarian processes largely stripped of their social dimensions in favour of controls that suit the IP holder. Social norms and systems of law enforcement become less significant actants as ownership, and subsequently possession, is increasingly assembled through code.

Such restrictions may potentially produce limited biographies in which movement between consumers is rare and an already individualised consumer culture (Bauman, 2007) becomes more so as social practices of consumption become less common. Indeed typically contractual agreements require an agreement between a singular individual and the company and thus whilst configurations of shared ownership have been documented, and are particularly prominent in certain cultures (see Belk 2010), ownership of DVGs is largely assembled by companies as singular, (with some exceptions such as iTunes Home Sharing).

Whilst sharing, lending and gifting practices may frequently be forbidden, this does not necessarily mean that they do not take place. As noted above, advice for removing DRM restrictions is available online, whilst consumers may also lend friends and family their e-reader or account 
details instead in order to circumvent companies' restrictions. Similarly, a look at popular video gaming forums reveals contributors planning to pass on their accounts to friends or family, or admitting to sharing an account with their partner, despite recognising that such actions are prohibited by contractual agreements. Thus ownership is not governed solely by corporations \& their interests but is shaped too by the end consumer whose sense of possession, and desire for established possession practices, still renders such restrictions difficult to enforce. However we speculate that the more important DVGs are to us the less likely we may be to take the risk of breaching contractual agreements since in doing so we risk losing access to our precious content, particularly given increased potential for companies' on-going surveillance of use.

Thus the more consumers invest meaning and value in DVGs the more agency companies' ownership configurations may come to hold over consumers' behaviour. The removal of clear legal actants in favour of company imposed agreements, surveillance measures and code brings with it new risks for consumers that have yet to be fully recognized.

\section{Contamination}

The meaning of material goods also involves contamination, understood as pollution or 'matter out of place' (Douglas, 1984), which is sought or avoided in transforming objects into personally meaningful possessions and in securing their sacred status (Belk, 1988; Belk et al. 1989). Negative pollutants (for example use by a stranger) are said to produce disgust or to profane the otherwise sacred dimension of possessions (Belk, 1988; Belk et al. 1989; Lastovicka and Fernández, 2005). Positive contamination too has been studied, with work concluding that proximity to another's body, or to sacred place or objects, charges items with positive meanings. For example, clothes once owned or worn by someone famous may be highly valued (Lastovicka and Miller 2012).

Digitally, such contamination may be present in negative messages accrued in social media platforms in hosted content ownership configurations and as market mediation is a focal force in the enactment of possession of DVGs market contamination may be a particular issue. For instance, digital music collections may be negatively contaminated by unwanted DVGs, as in the case of Apple 
automatically downloading a U2 album onto consumers' iTunes playlists for promotional reasons (Williams, 2014). As user data is also 'owned' by service providers and used for marketing any of consumers' accounts may also be contaminated by advertising content. Treasured archives on social media or email may only be accessed with accompanying, targeted advertising. The enactment of possession of many DVGs sees the speed and volume of pollutants increased with consumers' lack of control. Yet the lack of sharing and transfer or physical touch may limit the possibility of positive contamination. For example, a digital file of a book manuscript by a famous author may not have the aura of a hand-written one.

\section{Stability}

Finally, we may consider how possessions provide continuity and stability for meaning and identity. Ideas relating to goods as 'extensions of the self' suggest that material possessions can serve as identity anchors, providing a sense of permanence in the world by maintaining the continuity of the self through time and across locations (Belk, 1990, 1991, 1992; Kleine Kleine and Allen, 1995; Schultz, Kleine and Kernan, 1989; Tobin 1996), whilst the loss of treasured possessions may result in a 'shrinkage of our personality, a partial conversion of ourselves to nothingness' (James, 1890, p.178). Investment of the self in possessions suggests a confidence that these items will indefinitely remain within the consumer's exclusive control (Penner, 1996), and where this assurance is absent possession is 'insecure' (Litwinski cited in Rudmin, 1990) and 'unstable' (Munzer, 1990). Rudmin (1990) proposes that only total ownership provides the security necessary to guarantee expectation of future use and enjoyment. In material consumption individuals assume stability in the objects they purchase, and that their rights of ownership will not later be revoked. In contrast, for access-based consumption, temporary rights to access and use goods is typically made explicit; we are aware that we must return our hired car by a specified date and in the DVG market subscription-based ownership configurations such as Spotify and Netflix also clearly position access as temporary. Yet in the case of the hosted content ownership configuration there may be a perception of permanence but no guarantee of continued access. 
In discussing ownership of social media content Werbin (2012, p.256) proposes that 'content produced by users remains their property, but only in name, as control over the market exchange of said property, as well as control over its perpetuation on the platform, occur wholly at the discretion of the corporation.' Accounts may not just be terminated for violation of the company's terms, but also for commercial reasons (including insolvency), whilst data loss is another risk. For instance, Scarabato, Carter-Schneider and Kedzior (2013) illustrate that in investing significant labour in Disney's adverworld 'Virtual Magic Kingdom' users developed a sense of co-ownership and an assumption of continued access, however Disney later terminated the platform (and consequently consumers' hosted content) and were within their legal rights to do so. Pearce and Artemesia (2009) document a similar instance of loss, documenting the experiences of self-proclaimed 'refugees' following the closure of their game world, 'Uru: Ages Beyond Myst'. Thus the continued persistence of hosted content is rarely certain. Even non-transferable licences are not beyond retrieval as demonstrated by Amazon in 2009 when copies of the eBooks '1984' and 'Animal Farm' by George Orwell were remotely deleted from consumers' Kindle devices (Stone, 2009).

Increasingly we see companies encouraging consumers' to engage in meaningful, long-term relationships with DVGs so that their actions can be monetised. For example in 2011 Google released an advertisement featuring a father sending anecdotes, photographs and videos to his daughter throughout her childhood via Google's email service, with the intention of one day reflecting on these emails together (Bazilian, 2011). Here Google specifically invites users to create treasured digital scrapbooks, whilst social media and blogs are also used for this purpose. Indeed, it was estimated that $5 \%$ of children under two have a social media profile (AVG, 2010), with parents increasingly uploading treasured photographs and messages to be read in years to come. Watkins and Molesworth (2012) also demonstrate that consumers do form strong emotional attachments to hosted DVGs within massive multiplayer online games (one participant talks lovingly of her World of Warcraft avatar, for example, describing her as 'my baby'). However consumers cannot rest assured that these lovingly crafted digital objects will remain available for their own reflection, let alone for their children to reflect on as adults. World of Warcraft provider Blizzard Entertainment, for example, retains the right 
to terminate an individual's account, 'for any reason or no reason, with or without notice' (Blizzard, 2014). Similarly Google does not guarantee the permanence of the platform it promotes as a depository for memories. Their lack of permanence again leads us to consider how such relationships with personally meaningful yet unstable digital virtual possessions may relate to consumer identity projects. Belk (1988) notes the potential for significant 'lessening' of the self where highly appropriated possessions (facilitated by the ability to access, use, transform and manage these items) are lost, and here appropriated digital virtual possessions may be lost is due to technology malfunction, account termination or service closure.

Yet consumers may again adopt new practices in response to this situation. For instance, in Watkins and Molesworth's (2012) study of video gamers one participant invested in a Security Token that generated one-time-use passwords in order to protect his Final Fantasy XI Online account from hackers in an attempt to increase continuity and control, whilst another responded to an experience of loss with deliberate emotional detachment from his digital virtual possessions in an attempt to protect himself from the consequences of anticipated future loss. Thus in contrast to permanent and temporary access, indefinite access to DVGs can produce tense and problematic possession where these DVGs are assembled as meaningful possessions.

\section{DISCUSSION AND CONCLUSIONS}

Previous studies of possession have privileged the agency of the consumer subject and whilst existing work by Epp and Price (2010) acknowledges the role of other actants in shaping possession, here we have illustrated that in the context of DVGs new ownership configurations become particularly important in the assembling of possession. Our analysis highlights a complex network of new actants, in particular illustrating the agency of code in restricting the behaviours of consumers in relation to these items in favour of the interests of corporations. We propose that these emerging configurations of ownership may also produce new configurations of possession whereby access to, use and management of DVGs as well their use as linking devices to others, may be compromised. A result is that achieving the alignment between self, object and others that establishes personally meaningful possession (Richins 1994) and facilitates self-extension (Belk 1988) may become 
problematic. Furthermore, where DVGs do become meaningful extensions of the self, we have seen that limited ownership configurations may leave possession susceptible to disruption, and therefore may leave consumers susceptible to the lessening of the self that may be caused by the loss of personally meaningful possessions (Belk 1988). In short, digital technologies have disrupted the established assemblages of ownership and possession, revealing their contingencies and allowing for new realities of both, for new networks of relationships, and for different ontological politics. For marketers and consumers this is resulting in both new opportunities (assess-based business models and new markets for digital virtual goods) and risks (possession without full ownership, a reduction in the desire to possess) as yet not fully understood.

Our analysis therefore contributes to critical discussions of digital virtual consumption (e.g. Bonsu \& Darmody, 2008; Sholtz, 2013; Terranova, 2000) by illustrating the ways in which ownership may both restrict the ways in which DVGs can come to be possessed, and result in consumer behaviours that (for now) resist attempts to limit ownership. Thus whereas Bardhi et al (2012) and others (e.g. Belk, 2013b; Rifkin, 2000) position DVGs as potentially liberating consumers from the burdens of ownership, our analysis draws attention to cases where consumers may be unable to control or exploit these goods fully, even where they are largely products of their own labour.

The ways in which consumers respond to these fragmented ownership forms presents a promising area for empirical work. Fragmented ownership structures present significant and yet to be fully realised consequences for the end consumers of DVGs and this is particularly problematic given the multitude of evidence to suggest that EULAs and Terms of Service agreements are rarely read. In Chee, Taylor and de Castell's (2012) study of online gamers only 3\% reported that they read the entire contractual agreement and $62 \%$ read none of its content, a finding echoed in a range of contexts including social media (Debatin, Lovejoy Horn \& Hughes, 2009; Gross \& Acquisti, 2005), smartphone applications (Cotton \& Bolan, 2012) and a broad array of third party software (Bakos, Marotta-Wurgler \& Trossen 2009). Even where contractual agreements are read their content may leave the consumer confused as to exactly what rights they hold, resulting in assumptions based on existing understandings of the relationship between possession and ownership (often drawing from 
experiences of material consumption). This may result in tensions where a corporation regards its offering as access to a service, but the consumer comes to perceive the same DVGs as possessions. Perhaps most worrying is the existence of DVGs within platforms (be it software or webpages) owned and controlled by corporations who are able to change the terms of contractual agreements at any time, assembling ownership in ways which best serves their current interests. Here we see potential for ensnarement whereby consumers invest labour, time or money into a platform and in doing so find it difficult to leave when the terms of use are changed. Thus whilst a consideration of the morality of DVG ownership structures was beyond the scope of this paper this is clearly an area demanding consideration. We note instances of consumers removing DRM and sharing and passing on 'nontransferable' accounts, for example, and here we witness clashes of agency. In particular the emergence of coping mechanisms to deal with unstable possession, such the attempts to regain control and decisions to detach oneself from DVGs, presents an interesting area for further study

More broadly, our analysis highlights the limitations of the emerging full ownership versus access dichotomy and leads us to question claims of the reduced relevance of ownership in studies of consumption (Bardhi et al, 2012; Belk, 2013a; Chen, 2009). Indeed, the assumption of this reduced relevance by marketers may lead them to exploit new commercial assemblages of fragmented ownership that restrict practices of possession by consumers, raising new public policy concerns. We argue that in its fragmentation ownership actually becomes increasingly significant in studies of possession, and consumption more broadly, potentially transforming existing consumer culture and market relations.

In conclusion, we have theorised the relation between ownership and possession, highlighting key points of intersection. We have then proposed that ownership configurations may limit consumers' scope of action relative to an object and that restrictions on consumers' ability to use and transform possessions may potentially inhibit their capacity to cultivate possession meaning, whilst the movement of a possession from one person to another, through practices such as gifting, divestment, bequeathing may exist only under certain configurations of ownership whereby the consumer's rights to the object are transferable. We have also argued that fragmented ownership 
configurations may leave possession susceptible to disruption; where the continuity of consumers' rights to an object is questionable possession may indeed be tense and unstable, with a threat of loss. Indeed, when an object is under the complete control of a consumer they may be able to avoid the negative contamination from other people and things that in consumer research has been described as degrading possessions. Furthermore, we propose that consumers' continued possession attempts may impinge upon the agency of ownership mechanisms within the market, potentially limiting the ability of ownership configurations to restrict behaviour as intended. In doing this we provide a framework for future empirical studies both in the context of DVGs and beyond. Indeed, whilst particularly evident in the DVG market, ownership is perhaps increasingly fragmented and always assembled, and the software component of many technologies brings about further complex fragmentation. A mobile phone may only work with licenced operating systems and service agreements with network providers, for example, and although it is possible to jailbreak a mobile phone in order to remove company imposed restrictions, this typically voids the device's warranty. Thus although DVGs present a particularly salient case, in part due to increased ability to monitor use and enforce restrictions, the understanding of ownership as existing in fragmented configurations and the conceptualisation of the relation of ownership and possession developed in this paper can be applied to a much broader range of contexts.

\section{References}

Ahuvia, A. C. (2005). Beyond the Extended Self: Loved Objects and Consumers' Identity Narratives. Journal of Consumer Research, 32 (1), 171-84. doi: 10.1086/429607

Amazon, 2014. Kindle Store Terms of Use. Retrieved from: http://www.amazon.com/gp/help/customer/display.html/ref=hp_left_v4_sib?ie=UTF8\&nodeId $=201014950$

Appadurai, A. (1986). Introduction: commodities and the politics of value. In A. Appadurai (Ed.), The Social Life of Things: Commodities in Cultural Perspective (pp. 3-63). Cambridge: Cambridge University Press. 
Araujo, L. (2007). Markets, Market-Making and Marketing. Marketing Theory, 7(3), 211-26.

Arsel, Z. \& Thompson, C. (2011). Demythologizing Consumption Practices: How Consumers Protect their Field-Dependent Capital from Devaluing Marketplace Myths. Journal of Consumer Research, 37, 791-806. doi: 10.1086/656389

Arthur, C. (2012, 3 September). No, Bruce Willis isn't suing Apple over iTunes rights. The Guardian. Retrieved from: http://www.theguardian.com/technology/blog/2012/sep/03/no-apple-brucewillis

Askegaard, S. \& Linnet, J.T. (2011). Towards an epistemology of consumer culture theory: Phenomenology and the context of context. Marketing Theory, 11(4), 381-404. doi: $10.1177 / 1470593111418796$

Attas, D. (2005). Liberty, Property, and Markets: A Critique of Libertarianism. England: Ashgate.

Attas, D. (2006). Fragmenting Property. Law and Philosophy, 25(1), 119-49. doi: 10.1007/s10982005-8758-0

AVG (2010). Would you want a digital footprint from birth? Retrieved from http://blogs.avg.com/view-from-the-top/would-you-want-a-digital-footprint-from-birth/

Bajde, D. (2013). Consumer culture theory (re)visits actor-network theory: Flattening consumption studies. Marketing Theory, 13(2), 227-242. doi: 10.1177/1470593113477887

Bakos, Y., Marotta-Wurgler, F. \& Trossen, D. R. (2009). Does Anyone Read the Fine Print? Consumer Attention to Standard Form Contracts. CELS 2009 4th Annual Conference on Empirical Legal Studies Paper. NYU Law and Economics Research Paper. http://dx.doi.org/10.2139/ssrn.1443256

Bardhi, F. \& Eckhardt, G.M. (2012). Access-Based Consumption: The Case of Car Sharing. Journal of Consumer Research, 39(4), 881-898. doi 10.1086/666376 
Bardhi, F., Eckhardt, G.M., \& Arnould, E. (2012). Liquid Relationship to Possessions. Journal of Consumer Research, 39(3), 510-529. doi: 10.1086/664037

Barnes \& Noble (2014). Nook Store Terms of Service. Retrieved from: http://www.barnesandnoble.com/include/nook_store_terms_of_service.asp

Bauman, Z. 2007. Consuming Life. Cambridge: Polity.

Bazilian, E. (2011, May 14). Google Kicks Off TV Campaign to Promote Chrome- Ads tug at heartstrings of Internet users. Adweek. Retrieved from: http://www.adweek.com/news/advertising-branding/google-kicks-tv-campaign-promotechrome-131322

Beaglehole, E. (1932). Properly: A Study in Social Psychology. New York: Macmillan.

Belk R.W. (1982). Acquiring, Possessing, and Collecting: Fundamental Processes in Consumer Behavior. In R. F. Bush \& S. D. Hunt (Eds.), Marketing Theory: Philosophy of Science Perspectives (pp. 185-190). Chicago: American Marketing Association,

Belk R.W. (1983). Acquisitiveness and Possessiveness: Criticisms and Issues. Proceedings, 1982 Annual Convention of the American Psychological Association Division of Consumer Psychology (pp.70-73.). Washingto DC: Americal Psychological Association.

Belk, R.W. (1988). Possessions and the Extended Self. Journal of Consumer Research, 15(2), 139168. Retrieved from: http://www.jstor.org/stable/2489522

Belk, R.W. (1990). The Role of Possessions In Constructing and Maintaining A Sense of Past. Advances In Consumer Research, 17(1), 669-676. Retrieved from: http://www.acrwebsite.org/search/view-conference-proceedings.aspx?Id=7083

Belk, R.W. (1991). "Possessions and the Sense of Past," Highways and Buyways: Naturalistic Research From the Consumer Behavior Odyssey, Provo: Association for Consumer Research, Russell W. Belk, ed., 114-130. 
Belk, R. W . (1992). Moving Possessions: An Analysis Based on Personal Documents from the 18471869 Mormon Migration. Journal of Consumer Research, 19 (3), 339-61. doi: 10.1086/209306

Belk, R.W. (2010). Sharing. Journal of Consumer Research, 36 (February), 715-34. doi: $10.1086 / 612649$

Belk, R.W. (2013a). Extended Self in a Digital World. Journal of Consumer Research, 40(3), 477500. doi: $10.1086 / 671052$

Belk, R.W. (2013b). You are what you can access: Sharing and collaborative consumption online. Journal of Business Research, 67(8), 1595-1600. doi: 10.1016/j.jbusres.2013.10.001

Belk, R. 2014. Ownership and Collecting. In: The Oxford Handbook of Hoarding and Acquiring edited by Randy O. Frost, Gail Steketee

Belk, R.W. and Coon, G.S. (1993). Gift Giving as Agapic Love: An Alternative to the Exchange Paradigm Based on Dating Experiences. Journal of Consumer Research. 20(3), 393-417. doi: $10.1086 / 209357$

Belk, R.W., Sherry Jr., J.F., \& Wallendorf, M. (1988). A Naturalistic Inquiry Into Buyer and Seller Behavior at a Swap Meet. Journal of Consumer Research, 14 (4), 449-70. Retrieved from: http://www.jstor.org/stable/2489153

Belk, R.W., Wallendorf, M. \& Sherry Jr., J.F. (1989). The Sacred and the Profane in Consumer Behavior: Theodicy on the Odyssey. The Journal of Consumer Research, 16(1), 1-38. doi: $10.1086 / 209128$

Bettany, S. and Kerrane, B. (2011). The (post-human) consumer, the (post-avian) chicken and the (post-object) Eglu: Towards a material-semiotics of anti-consumption. European Journal of Marketing, 45(11/12), 1746 - 1756. doi: http://dx.doi.org/10.1108/03090561111167388

Blizzard (2014). World of Warcraft End User Licence Agreement. Retrieved from http://us.blizzard.com/en-us/company/legal/wow_eula.html 
Bonsu, S. K. \& Darmody, A. (2008). Co-Creating Second Life: Firm-Consumer Co-operation in Contemporary Economy. Journal of Macromarketing, 28(December), 355-368. doi: $10.1177 / 0276146708325396$

Callon, M. (1997). The Laws of the Markets. Oxford, UK: Blackwell.

Carroll, E. and Romano, J. (2010). Your Digital Afterlife: When Facebook, Flickr and Twitter Are Your Estate, What's Your Legacy? Berkeley, CA: New Rider's Press.

Chee, F. M., Taylor, N. T. and de Castell, S. (2012). Re-Mediating Research Ethics End-User License Agreements in Online Games. Bulletin of Science Technology Society December, 32 (6), 497506. doi:10.1177/0270467612469074.

Chen, Y. (2009). Possession and Access: Consumer Desires and Value Perceptions Regarding Contemporary Art Collection and Exhibit Visits. Journal of Consumer Research, 35 (April), 925-40. doi: 10.1086/593699

Child, B. (2012, Monday 3). Bruce Willis to fight Apple over right to leave iTunes library in will. The Guardian. Retrieved from: http://www.theguardian.com/film/2012/sep/03/bruce-willis-appleitunes-library

Cochoy, F. (2008). Calculation, Qualculation, Calqulation: Shopping Cart Arithmetic, Equipped Cognition and the Clustered Consumer. Marketing Theory, 8(1), 15-44.

Cooks, R. (2014, May 21). Spotify streams past rivals as it doubles subscriber base to $10 \mathrm{~m}$. Financial Times. Retrieved from: http://www.ft.com/cms/s/0/a9fa8fea-e0cf-11e3-875f00144feabdc0.html\#axzz34jHUVpci

Cotton, H. S. \& Bolan, C. M. (2012). User Reaction Towards End User License Agreements on Android Smartphones. Proceedings of International Conference on Security and Management. (pp. 666-668). Las Vegas, Nevada, USA. CSREA Press. 
Debatin, B., Lovejoy, J. P., Horn, A. K., \& Hughes, B. N. (2009). Facebook and online privacy: Attitudes, behaviors, and unintended consequences. Journal of Computer-Mediated Communication, 15, 83-108. doi:10.1111/j.1083-6101.2009.01494.x

Demsetz, H. (1967). Toward a Theory of Property Rights. The American Economic Review, 2, 34759.

Denegri-Knott, J. \& Molesworth, M. (2009). 'I'll sell this and I'll buy them that': Ebay and the management of possessions as stock. Journal of Consumer Behaviour, 8(6), 305-315. doi: $10.1002 / \mathrm{cb} .295$

Denegri-Knott, J. \& Molesworth, M. (2010). Concepts and Practices of Digital Virtual Consumption. Consumption, Markets \& Culture, 13(2), 109-132. doi: 10.1080/10253860903562130

Denegri-Knott, J., Watkins, R. \& Wood, J. (2012). Transforming Digital Virtual Goods into Meaningful Possessions. In M. Molesworth \& J. Denegri-Knott (Eds.), Digital Virtual Consumption (pp. 76-91). Oxford: Routledge.

Douglas, M. (1984). Purity and Danger: An Analysis of the concept of pollution and taboo. London: Routledge and Kegan Paul.

Durgee, J., \& O’Connor, G. (1995). An exploration into renting as consumption behavior. Psychology and Marketing, 12, 89-104.

Epp, A., \& Price, L. (2010). The Storied Life of Singularised Objects: Forces of Agency and Network Transformation. Journal Of Consumer Research, 36(5), 820-837. doi: 10.1086/603547

Etzioni, A. (1991). The Socioeconomics of Property. Journal of Social Behavior and Personality, $6(6), 465-468$.

Facebook (2014). Statement of Rights and Responsibilities. Retrieved from: https://www.facebook.com/legal/terms 
Faulkner, P. \& Runde, J. (2011) The social, the material, and the ontology of non-material technological objects. Paper presented at the European Group for Organizational Studies (EGOS) Colloquium, Gothenburg.

Freeman, E.H. (2002). The Digital Millennium Copyright Act. Information Systems Security, 11(4), 4-8. doi: 10.1201/1086/43322.11.4.20020901/38840.2

Garrahan, M. (2014, January 22). Netflix Subsctibers Numbers Surge. Financial Times. Retrieved from: http://www.ft.com/cms/s/0/e4dde050-83b7-11e3-aa6500144feab7de.html\#axzz34jHUVpci

Gaus, G. (2012). Property and Ownership. In Estlund D. (Ed.) Oxford Handbook of Political Philosophy (93-112). Oxford: Oxford University Press,

Giesler, M. (2006). Consumer Gift System. Journal of Consumer Research, 33 (September), 283-90. doi: $10.1086 / 506309$

Giesler, M. (2008). Conflict and Compromise: Drama in Marketplace Evolution. Journal of Consumer Research, 34 (April), 739-753. doi: 10.1086/522098

Giesler, M. (2012). How Doppelganger Brand Images Influence the Market Creation Process: Longitudinal Insights from the Rise of Botox Cosmetic. Journal of Marketing, 76(6), 55-68. doi: http://dx.doi.org/10.1509/jm.10.0406

Giesler, M. \& Humphreys, A. (2007). Tensions between Access and Ownership in the Media Marketplace. Advances in Consumer Research, 34, 696-700. Retrieved from: http://www.acrwebsite.org/search/view-conference-proceedings.aspx ?Id=12813

Grayson, K. \& Schulman D. (2000). Indexicality and the Verification Function of Irreplaceable Possessions: A Semiotic Analysis. Journal of Consumer Research, 27(June), 17-30. doi: $10.1086 / 314306$

Gregson, N. \& Crewe, L. (2003). Second-Hand Cultures. Oxford: Berg Publishers. 
Grey, T. (1980). The Disintegration of Property. In R.J. Pennock \& J.W. Chapman (Eds.), Property: Nomos XXII (pp.69-86). New York: New York University Press.

Gross, R. \& Acquisti, A. (2005). Information revelation and privacy in online social networks. In Proceedings of the 2005 ACM Workshop on Privacy in the Electronic Society (pp. 71-80). New York, NY: ACM.

Haase, M. \& Kleinaltenkamp, M. (2011). Property Rights Design and Market Process: Implications for Market Theory, Marketing Theory, and S-D Logic. Journal of Macromarketing, 31(2), 148 159. doi: $10.1177 / 0276146710397662$

Harwood, T. \& Garry, T. (2010). 'It's Mine!' - Participation and ownership within virtual co-creation environments. Journal of Marketing Management, 26, 290-301. doi: $10.1080 / 02672570903566292$

Harwood, T. \& Garry, T. (2014). Co-creation and ambiguous ownership within virtual communities: the case of the Machinima community. Journal of Consumer Behaviour, 13, 148-156. doi: $10.1002 / \mathrm{cb} .1437$

Hegel, G. W. F. (1967/1821). The Philosophy of Right. Cambridge: Cambridge University.

Honoré, A.M. (1961). Ownership. In Anthony G. Guest (Ed.) Oxford Essays in Jurisprudence (pp.107-47), London: Oxford University Press.

Isaacs, S. (1933). Social Development in Young Children. London: Routledge \& Kegan Paul.

James, W. (1890). The Principles of Psychology, Vol.1. New York: Henry Holt.

Jenkins, R., Molesworth, M. \& Scullion, R. (2014). The Messy Social Lives of Objects: Interpersonal Borrowing and the Ambiguity of Possession and Ownership. Journal of Consumer Behaviour, 13(2), 131-139. doi: 10.1002/cb.1469

Katz, L. (2008). Exclusion and Exclusivity in Property Law. University of Toronto Law Journal, 58(3), 275-315. doi: 10.3138/utlj.58.3.275 
Kleine, S.S., Kleine III, R.E. \& Allen, C.T. (1995). How Is a Possession 'Me' or 'Not Me'?

Characterizing Types and an Antecedent of Material Possession Attachment. Journal of Consumer Research, 22 (Dec), 327-343. Retrieved from: http://www.jstor.org/stable/2489618

Koiso-Kanttil, N. (2004) Digital Content Marketing: A Literature Synthesis. Journal of Marketing Management, 20(1-2), 45-65. doi: 10.1362/026725704773041122

Kopytoff, I. (1986). The cultural biography of things, commoditization as a Process. In A. Appadurai (Ed.) The Social Life of Things Commodities in a Cultural Perspective (pp. 64-94). Cambridge University Press: Cambridge,

Lastovicka, J. L. \& Fernandez, K.V. (2005). Three Paths to Disposition: The Movement of Meaningful Possessions to Strangers. Journal of Consumer Research, 31(March), 813-832. doi: $10.1086 / 426616$

Lastovicka, J. L. \& Miller, C. J. (2012). Proximal and Contagious Indexicality: Unpacking the Meanings of Celebrity-Owned Objects. In R. W. Belk, S. Askegaard, \& L. Scott (Eds.), Research in Consumer Behavior, Volume 14 (pp. 317-332). Bingley: Emerald Group. doi: 10.1108/S0885-2111(2012)0000014020

Lastovicka, L.J. \& Sirianni, N.J. (2011). Truly, Madly, Deeply: Consumers in the Throes of Material Possession Love. Journal of Consumer Research, 38(2), 323-342. doi: 10.1086/658338

Latour, B. (2005). Reassembling the Social: An Introduction to Actor-Network Theory. Oxford, UK: Oxford University Press

Law, J. (2004). After Method: Mess in Social Science Research. Oxon: Routledge.

Law, J. (2008). Actor-network theory and material semiotics. In: Turner, Bryan S. ed. The New Blackwell Companion to Social Theory, 3rd Edition. Oxford: Blackwell, pp. 141-158.

Lehdonvirta, V. (2012). A history of the digitalization of consumer culture: From Amazon through Pirate Bay to Farmville. In J. Denegri-Knott \& M. Molesworth (Eds.), Digital Virtual Consumption (pp.11-28). New York: Routledge. 
Lehdonvirta, V. and Castronova, E. (2014). Virtual Economies: Design and Analysis. Cambridge, MA: MIT Press.

Lessig, L. (1999). Code: and Other Laws of Cyberspace. New York: Basic Books.

Linden Research (2014). Linden Lab Terms of Service. Retrieved from: http://lindenlab.com/tos

Locke, J. (1690[1967]). Two treatises of government. Oxford: Oxford University Press.

Macpherson, C.B. (1978). Property: Mainstream and Critical Positions. Oxford: Blackwell.

Manley, L. \& Holley, R.P. (2012). History of the Ebook: The Changing Face of Books. Technical Services Quarterly, 29(4), 292-311. doi: 10.1080/07317131.2012.705731

McCracken, G. (1986). Culture and Consumption: A theoretical account of the structure and movement of the cultural meaning of consumer goods. Journal of Consumer Research, 13(June), 71-84. Retrieved from: http://www.jstor.org/stable/2489287

MacKenzie, D.A., Muniesa, F. and Siu, L. (2007). Do Economists Make Markets? On the Performativity of Economics. Princeton, NJ; Woodstock: Princeton University Press.

Miller, D. (1987). Material Culture and Mass Consumption. Oxford: Blackwell.

Moeller, S. \& Wittkowski, K. (2010). The burdens of ownership: reasons for preferring renting. Managing Service Quality, 20(2), 176-191. doi: 10.1108/09604521011027598

Moisander, J., Penãloza, L. \& Valtonen, A. (2009). From CCT to CCC. Building Consumer Culture Community. In J. F. Sherry Jr \& E. Fischer (Eds.) Explorations in Consumer Culture Theory (pp. 7-33). London: Routledge.

Moisander, J., Valtonen, A. \& Hirsto, H. (2009). Personal Interviews in Cultural Consumer Research - Post-structuralist Challenges. Consumption, Markets and Culture, 12(4), 329-48. doi: $10.1080 / 10253860903204519$

Mol, A. (1999). Ontological politics: A word and some questions. In J. Law and J. Lassard (eds.), Actor Network Theory and After (pp. 74-89). Malden, MA: Blackwell. 
Molesworth, M. \& Denegri-Knott, J. (2012). Digital Virtual Consumption. Oxford: Routledge.

Munzer, S. R. (1990). A Theory of Property. Cambridge: Cambridge University Press.

Nill, A., Giepe, A. Jr. (2010). Sharing and Owning of Musical Works: Copyright Protection from a Societal Perspective. Journal of Macromarketing, 30(1), 33-49. doi: $10.1177 / 0276146709352217$

Odom, W., Banks, R., Kirk, D, Harper, R., Lindley, S., Sellen, A. (2012). Technology Heirlooms? Considerations for Passing Down and Inheriting Digital Materials. In proceedings of SIGCHI Conference on Human Factors in Computing Systems. Austin, Texas. CHI '12. ACM Press. http://dx.doi.org/10.1145/2207676.2207723

Odom, W., Harper, R., Sellen, A., Kirk, D., Banks, R. (2010). Passing On \& Putting To Rest: Understanding Bereavement in the context of Interactive Technologies. In proceedings of SIGCHI Conference on Human Factors in Computing Systems. Atlanta, USA. CHI '10. ACM Press, 1831-1840. http://dx.doi.org/10.1145/1753326.1753601

Odom, W., Zimmerman, J., Forlizzi, J. (2011). Teenagers and their virtual possessions: design opportunities and issues. CHI '11 - Proceedings of the SIGCHI Conference on Human Factors in Computing Systems, 1491-1500. doi: 10.1145/1978942.1979161

Ozanne, L. \& Ballantine, P. (2010). Sharing as a Form of Anti-consumption? An Examination of Toy Library Users. Journal of Consumer Behavior, 9(6), 485-98. doi: 10.1002/cb.334

Pearce, C. and Artemesia (2009). Communities of Play: Emergent Cultures in Multiplayer Games and Virtual Worlds. Cambridge, MA: MIT Press.

Peck, J. and Shu, S. B. (2009). The Effect of Mere Touch on Perceived Ownership. Journal of Consumer Research, 36(3), 434-447.

Peitz, M. \& Waelbroeck, P. (2006). Piracy of digital products: A critical review of the theoretical literature. Information Economics and Policy, 18(4), 449-476. doi: 10.1016/j.infoecopol.2006.06.005 
Penner, J. (1996). The 'Bundle of Rights' Picture of Property, UCLA Law Review, 43 (3), 711-820.

Phau, I., Teah, M. \& Lwin, M. (2014). Pirating Pirates of the Caribbean: The curse of cyberspace. Journal of Marketing Management, 30(3-4), 312-333. Doi: 10.1080/0267257X.2013.811280

Pierce, J.L., Kostova, T., \& Dirks, K.T. (2003). The state of psychological ownership: Integrating and extending a century of research. Review of General Psychology, 7(1), 84-107. doi: $10.1037 / 1089-2680.7 .1 .84$

Price, L., Arnould, E., \& Curasi, C. (2000). Older Consumers' Disposition of Special Possessions. Journal of Consumer Research, 27(2), 179-201. Retrieved from: http://www.jstor.org/stable/10.1086/314319

Richins, M.L. (1994a). Special Possessions and the Expression of Material Values. Journal of Consumer Research, 21(3), 522-533. Retrieved from: http://www.jstor.org/stable/2489690

Richins, M.L. (1994b) Valuing Things: The Public and Private Meanings of Possessions. Journal of Consumer Research, 21 (3), 504-521. Retrieved from: http://www.jstor.org/stable/2489689

Rifkin, J. (2000). The Age of Access: The New Culture of Hypercapitalism Where All of Life Is a Paid for Experience. New York: Penguin.

Rifkin, J. (2002). The Age of Access, The New Politics of Culture vs. Commerce, Ars Electronica. Retrieved from: http://90.146.8.18/en/archives/festival_archive/festival_catalogs/festival_artikel.asp?iProjectID $=11765$

Rifkin, J. (2014). The Zero Marginal Cost Society. Palgrave, New York.

Ritzer, G. \& Jurgenson, N. (2010). Production, Consumption, Prosumption: The nature of capitalism in the age of the digital 'prosumer'. Journal of Consumer Culture, 10(1), 13-36. doi: $10.1177 / 1469540509354673$ 
Rowley, J. (2008). Understanding digital content marketing. Journal of Marketing Management, 24 (5-6), 517-540. doi: 10.1362/026725708X325977

Rudmin, F.W. (1988). Ownership as Interpersonal Dominance: A History and Three Studies of the Social Psychology of Property. Unpublished Doctoral Dissertation.

Rudmin, F.W. (1990). The economic psychology of Leon Litwinski (1987-1969): A program of cognitive research on possession and property. Journal of Economic Psychology, 11, 307-339.

Rudmin, F.W. (Ed.) (1991). To Have Possessions: A Handbook on Ownership and Property. A Special Issue of the Journal of Social Behaviour and Personality, 6(6).

Ryder, R.D. and Madhavan, A. (2014) Intellectual Property and Business: The Power of Intangible Assets. London: Sage.

Scaraboto, D., Carter-Schneider, L. \& Kedzior, R. (2013). At world's end: Exploring consumermarketer tensions in the closure of adverworlds. Journal of Marketing Management, 29(13-14), 1518-1541. doi: 10.1080/0267257X.2013.833968

Scarabato, D. \& Fischer, E. (2013). Frustrated Fatshionistas: An Institutional Theory Perspective on Consumer Quests for Greater Choice in Mainstream Markets. Journal of Consumer Research, 39(April), 1234-57. doi: 10.1086/668298

Shaefer, T., Lawson, S.J. \& Kukar-Kinney, M. (forthcoming). How the burdens of ownership promote consumer usage of access-based services. Marketing Letters. DOI 10.1007/s11002-015-9366-X

Schlatter, R. (1951). Private Property: The History of an Idea. New Brunswick, NJ: Rutgers University Press.

Scholz, T. (2013). Digital Labor: The Internet as Playground and Factory. New York: Routledge.

Schultz, S.E., Kleine, III, R.E. \& Kernan, J.B. (1989). ‘These Are a Few of My Favorite Things': Toward an Explication of Attachment as a Consumer Behavior Construct. In Srull, T. (Ed.) Advances in Consumer Research Vol.16 (p. 359-66). Provo, UT: Association for Consumer 
Research. Retrieved from: http://www.acrwebsite.org/search/view-conferenceproceedings.aspx $? \mathrm{Id}=6931$

Slater, D. (2002). From Calculation to Alienation: Disentangling Economic Abstractions. Economy and Society, 31(2), 234-49.

Slater, D. (2011). Marketing as a monstrosity: the impossible place between culture and economy. In D. Zwick \& J. Cayla (Eds.), Inside marketing: practices, ideologies, devices (pp. 23-41). Oxford: Oxford University Press.

Snare, F. (1972). The Concept of Property. American Philosophical Quarterly, 9 (2), 200-06.

Stone, B. (2009, July 17). Amazon Erases Orwell Books From Kindle. New York Times. Retrieved from: http://www.nytimes.com/2009/07/18/technology/companies/18amazon.html?_r=0

Sundararajan, A. (2004). Managing Digital Piracy: Pricing and Protection. Information Systems Research, 15(3), 287-308. doi: 10.1287/isre.1040.0030

Terranova, T. (2000). Free Labor: producing culture for the digital economy. Social Text, 18 (2), 3358.

Tobin, S.S. (1996). Cherished Possessions: The Meaning of Things. Generations, 20(3), 46-49

Wallendorf, M. \& Arnould, E. (1988). 'My Favorite Things': A Cross-Cultural Inquiry into Object Attachment, Possessiveness, and Social Linkage. Journal of Consumer Research, 14 (March), 531-547. doi: http://www.jstor.org/stable/2489159

Wang, J., Zhao, X. and Bamossy, G. J., 2009. "The Sacred and the Profane in Online Gaming: A Netnographic Inquiry of Chinese Gamers.” In: Natalie T. Wood and Michael R. Solomon, ed., Virtual Social Identity and Consumer Behavior, Armonk, NY: M. E. Sharpe, 109-124.

Watkins, R. \& Molesworth, M. (2012). Attachment to Digital Virtual Possessions in Videogames. Research in Consumer Behavior, 14, 153-171. doi: 10.1108/S0885-2111(2012)0000014012 
Watson, M. and Shove, E. 2008. Product, Competence, Project and Practice DIY and the dynamics of craft consumption. Journal of Consumer Culture. 8, 1, p. 69-89.

doi: $10.1177 / 1469540507085726$

Werbin, K.C. (2012). The Social Media Contract: On the Paradoxes of Digital Property in This Digital Land. Journal of Canadian Studies, 46(2)5-262.

Williams, M. (2014, September 9). Half a billion iTunes customers receive latest U2 album for free. The Guardian. Retrieved from: http://www.theguardian.com/music/2014/sep/09/u2-songs-ofinnocence-itunes-customers-free-album

Wong, C. (2012). Can Bruce Willis Leave His iTunes Collection to His Children?: Inheritability of Digital Media in the Face of EULAs. Santa Clara High Technology Law Journal, 29(4), $703-$ 761. Retrieved from: http://digitalcommons.law.scu.edu/chtlj/vol29/iss4/5 